\title{
Ruania albidiflava gen. nov., sp. nov., a novel member of the suborder Micrococcineae
}

\author{
Qiang Gu, ${ }^{1,2}$ Mariola Paściak, ${ }^{3}$ Hongli Luo, ${ }^{1}$ Andrzej Gamian, ${ }^{3}$ Zhiheng Liu ${ }^{1}$ \\ and Ying Huang ${ }^{1}$ \\ 'State Key Laboratory of Microbial Resources, Institute of Microbiology, Chinese Academy of \\ Sciences, Beijing 100101, PR China \\ ${ }^{2}$ Graduate University of Chinese Academy of Sciences, Beijing 100049, PR China \\ ${ }^{3}$ Laboratory of Medical Microbiology, Institute of Immunology and Experimental Therapy, Polish \\ Academy of Sciences, Rudolfa Weigla 12, 53-114 Wroclaw, Poland
}

Correspondence

Ying Huang

huangy@im.ac.cn
According to the estimation performed by Hammond (1995), the number of bacteria that have been successfully isolated and identified comprises only a small portion of the total that exist in nature. In the past decade, the Micrococcineae (Stackebrandt et al., 1997) has been one of the most studied suborders in the class Actinobacteria; numerous novel taxa in this suborder have been cultured and described (Martin et al., 1997; Groth et al., 1999a, b, 2001, 2002; von Wintzingerode et al., 2001; Altenburger et al., 2002; Takahashi et al., 2006). In the current study, we describe a bacterium isolated from farmland soil collected in Shandong Province, China, and propose a novel species of a new genus in the suborder Micrococcineae.

Farmland soil samples were collected from a cotton field in Shandong Province. A $1 \mathrm{~g}$ soil sample was suspended in $10 \mathrm{ml}$ sterile distilled water and mixed thoroughly by shaking overnight at room temperature. The suspension was

The GenBank/EMBL/DDBJ accession number for the $16 \mathrm{~S}$ rRNA gene sequence of strain $3-6^{\top}$ is D0343153.

A scanning electron micrograph of cells of strain $3-6^{\top}$, a maximumparsimony phylogenetic tree and tables detailing the physiological and biochemical properties and cellular fatty acid components of strain $3-6^{\top}$ are available as supplementary material in IJSEM Online. serially diluted and spread onto yeast extract-starch agar (JCM medium no. 42) plates, followed by incubation for 1 week under humid conditions at $28^{\circ} \mathrm{C}$. The organism thus isolated, designated strain $3-6^{\mathrm{T}}$, was picked and transferred to fresh nutrient agar for purification. The pure culture was tested for growth in various media and was maintained on nutrient agar slants at $4{ }^{\circ} \mathrm{C}$.

For observation of colony and cell morphology, strain 3-6 was grown on nutrient agar, R agar (Groth et al., 1999b) and trypticase soy agar (TSA; BBL) for up to 5 days at $28^{\circ} \mathrm{C}$. Light and scanning electron micrographs were taken according to methods described previously (Huang et al., 2004). The presence of flagella was examined via transmission electron microscopy of 48- and 72-h plate cultures. The temperature range for growth was determined by incubating inoculated slant agar cultures ( $\mathrm{R}$ medium, $\mathrm{pH}$ 7.0) at 4, 10, $15,20,28,37$ and $45^{\circ} \mathrm{C}$. Growth was also assessed on R agar plates at initial $\mathrm{pH}$ values of 3.5-13.5. The lower $\mathrm{pH}$ values of the test medium were obtained according to the method described by Cui et al. (2005) and $\mathrm{pH}$ values above 10.5 by using a buffer system of disodium hydrogen phosphate $(0.15 \mathrm{M})$ /sodium hydroxide $(6 \mathrm{M})$. API $50 \mathrm{CH}$ and API ZYM kits (bioMérieux) were used to test acid production from carbohydrates and enzyme activities, respectively. In 
addition, susceptibility to antibiotics was assessed as described by Groth et al. (1999b), use of sole carbon sources for energy and growth was determined by using the methods of Yassin et al. (1995) and biodegradation tests were performed according to the procedures described by Gordon \& Mihm (1957).

Genomic DNA extraction and PCR amplification of the $16 \mathrm{~S}$ rRNA gene from strain 3-6 $6^{\mathrm{T}}$ were performed by using an established method (Chun \& Goodfellow, 1995). The PCR product was purified and cloned into the vector pMD 18-T (Takara) by using the method and reagents provided by the manufacturer. The almost-complete nucleotide sequence of the 16S rRNA gene was obtained according to the process described by Gu et al. (2006), except that M13 sequencing primers were used. Preliminary phylogenetic analysis was performed with the BLAST search program available at NCBI. Selected sequences were loaded into the software package MEGA, version 3.1 (Kumar et al., 2004), and this was followed by a series of programmed phylogenetic calculations. Neighbour-joining (Saitou \& Nei, 1987) and maximumparsimony (Fitch, 1971) trees were constructed separately as described by Gu et al. (2006).

Cell mass of strain $3-6^{\mathrm{T}}$ was collected from 4-day cultures in liquid $\mathrm{R}$ medium. Isoprenoid quinones were purified according to the methods of Collins (1985) and were analysed by HPLC (Wu et al., 1989) by using an HP-1050 (Hewlett Packard) chromatograph equipped with a Zorbax ODS C18 $(250 \times 4.6 \mathrm{~mm}$, inner diameter $5 \mu \mathrm{m})$ column. The mobile phase was acetonitrile/2-propanol $(2: 1)$ at a flow rate of $1 \mathrm{ml} \mathrm{min}^{-1}$, and menaquinones were detected by absorption at $270 \mathrm{~nm}$. Polar lipids were extracted and identified by two-dimensional TLC (Lechevalier et al., 1977; Minnikin et al., 1984). The fatty acid profile was determined according to the GC techniques described by Sasser (1990) and Kämpfer \& Kroppenstedt (1996). The acid methanolysis procedure was used to detect mycolic acids (Minnikin et al., 1975). To determine the peptidoglycan structure, purified cell wall was prepared according to the method of Lechevalier \& Lechevalier (1970). Amino acids and peptides in the cell-wall hydrolysates were examined by TLC as described by Schleifer \& Seidl (1985) and with LC-MSMS by using a micrOTOF-Q instrument (Bruker). Subsequently, GLC-MS analyses of heptafluorobutyrate derivatives of amino acids (MacKenzie \& Tenaschuk, 1974) were performed to determine the enantiomeric amino acid isomers and their molar ratios. Derivatives were prepared by acidcatalysed esterification at $120{ }^{\circ} \mathrm{C}$ for 20 min with $R-(-)-2$ butanol $(200 \mu \mathrm{l})$ and acetyl chloride $(20 \mu \mathrm{l})$ followed by acylation with heptafluorobutyric anhydride at $150{ }^{\circ} \mathrm{C}$ for 5 min. GLC-MS analyses were performed with a Hewlett Packard 5971A system, employing an HP-1 glass capillary column $(0.2 \mathrm{~mm} \times 12 \mathrm{~m})$, a temperature program of 100 $270^{\circ} \mathrm{C}$ at $5^{\circ} \mathrm{C} \mathrm{min}^{-1}$, with helium as the carrier gas and at a split ratio of $1: 50$. The N-terminal amino acid of the interpeptide bridge was determined by dinitrophenylation as described by Schleifer (1985). Whole cell-wall sugars were analysed according to the method of Lechevalier \& Lechevalier (1980). The G+C content of the genomic DNA of strain 3-6 $6^{\mathrm{T}}$ was determined by the thermal denaturation method (Marmur \& Doty, 1962) with Escherichia coli $\mathrm{K}-12$ as a control.

After 3 days incubation, strain $3-6^{\mathrm{T}}$ was found to grow well and formed convex and moist colonies that were whitishyellow in colour. Cells were small cocci, $0.5-0.8 \mu \mathrm{m}$ in diameter (see Supplementary Fig. S1 in IJSEM Online). Neither flagella nor a rod-coccus life cycle were detected when grown in the media mentioned above. Growth was observed between 20 and $37^{\circ} \mathrm{C}$, with optimum growth at $28^{\circ} \mathrm{C}$. Growth was also observed on $\mathrm{R}$ agar at initial $\mathrm{pH}$ values ranging from 5.5 to 12.5 , with optimum growth at $\mathrm{pH}$ 6.5-10.5. Detailed physiological and biochemical characteristics of strain $3-6^{\mathrm{T}}$, including acid production from carbohydrates, assimilation of sole carbon sources, enzyme activities and antibiotic susceptibilities, are given in Supplementary Table S1 available in IJSEM Online.

GLC-MS analysis of cell-wall amino acids revealed that the peptidoglycan of strain $3-6^{\mathrm{T}}$ contained L-Ala, D-Ala, Gly, L-Glu, D-Glu and L-Lys in a molar ratio of $1.0: 0.7: 0.7: 1.7: 0.9: 0.7$. Dinitrophenylated Glu was detected in hydrolysates of cell-wall preparations treated with 1-fluoro-2,4-dinitrobenzene. From these results and from the occurrence of the peptides $\mathrm{L}-\mathrm{Lys} \leftarrow \mathrm{Gly}$ and $\mathrm{L}-\mathrm{Glu} \leftarrow \mathrm{D}$-Ala in the two-dimensional TLC peptide pattern of the partial hydrolysates of the cell walls (data not shown), it was concluded that strain $3-6^{\mathrm{T}}$ possesses a peptidoglycan of type A4 $\alpha$ (Schleifer \& Kandler, 1972) with an L-Lys $\leftarrow$ Gly $\leftarrow \mathrm{L}-\mathrm{Glu} \leftarrow \mathrm{L}-\mathrm{Glu}$ interpeptide bridge, which is a novel murein type according to the DSMZ catalogue of strains (http://www.dsmz.de/species/murein.htm). The whole-cell sugars consisted mainly of galactose and glucose. The major menaquinone was the partially saturated menaquinone MK-8 $\left(\mathrm{H}_{4}\right)$. Phosphatidylglycerol, diphosphatidylglycerol and one unknown glycolipid were found as major polar lipids. Cellular fatty acid analysis revealed predominant amounts of the branched fatty acids anteiso$\mathrm{C}_{15: 0}(37.3 \%)$, anteiso- $\mathrm{C}_{17: 0}(14.7 \%)$ and iso- $\mathrm{C}_{16: 0}$ (14.3\%) and smaller amounts of $\mathrm{C}_{18: 1} \omega 9 c(9.5 \%)$, iso$\mathrm{C}_{15: 0}(7.9 \%), \mathrm{C}_{16: 0}(5.9 \%)$, iso- $\mathrm{C}_{17: 0}(2.6 \%)$ and $\mathrm{C}_{14: 0}$ $(1.9 \%)$. The complete fatty acid profile is given in Supplementary Table S2 in IJSEM Online. Mycolic acids were not present. The $\mathrm{G}+\mathrm{C}$ content of the genomic DNA of strain $3-6^{\mathrm{T}}$ was $69.8 \mathrm{~mol} \%$.

The nearest phylogenetic neighbours of strain $3-6^{\mathrm{T}}$, as determined by analysis of the almost-complete $16 \mathrm{~S}$ rRNA gene sequences, were found to be members of the suborder Micrococcineae. Highest sequence similarity was obtained with Georgenia muralis $1 \mathrm{~A}-\mathrm{C}^{\mathrm{T}}(94.2 \%)$. The position of strain $3-6^{\mathrm{T}}$ relative to its phylogenetic neighbours is shown in the neighbour-joining tree (Fig. 1) and was confirmed in the maximum-parsimony tree (see Supplementary Fig. S2 in IJSEM Online). The pattern of its 16S rRNA gene sequence signature nucleotides is shown in Table 1, which 


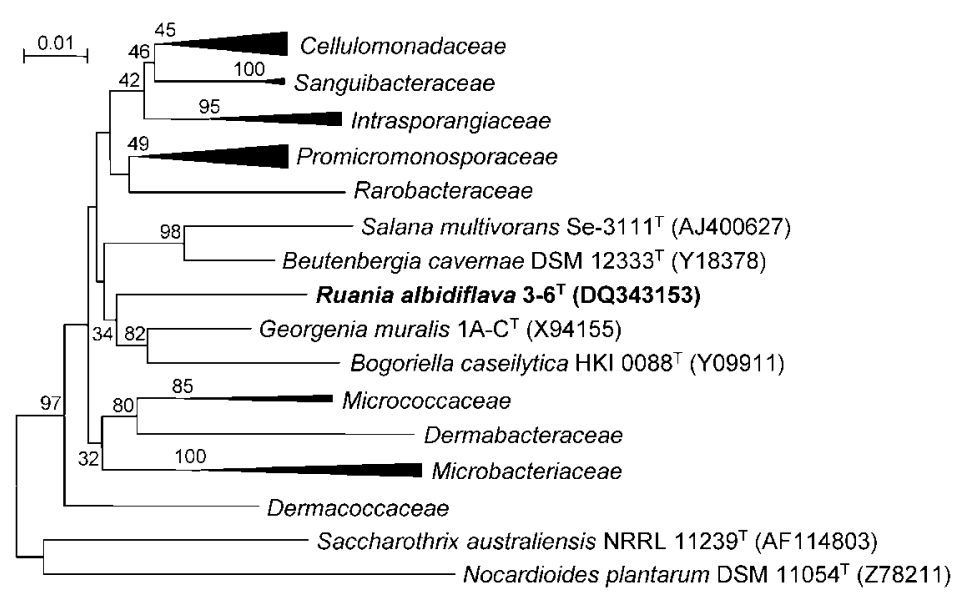

Fig. 1. Phylogenetic analysis based on $16 \mathrm{~S}$ rRNA gene sequences available from the GenBank/EMBL/DDBJ databases displaying relationships between strain $3-6^{\top}$ and related taxa. Distances with the Kimura two-parameter model (Kimura, 1980) were determined and clustering with the neighbour-joining method were performed by using the software package MEGA, version 3.1 (Kumar et al., 2004). Bootstrap values based on 1000 replications are listed as percentages at branch points. The taxa and sequences included in the family groups are the same as shown in Supplementary Fig. S2 (available in IJSEM Online). Bar, 0.01 substitutions per nucleotide position. indicated that strain 3-6 $6^{\mathrm{T}}$ does not belong to any recognized family within the suborder Micrococcineae, having the fewest signature nucleotide differences with Georgenia (seven of 33 positions) and the Bogoriellaceae (eight of 33 positions) (Stackebrandt et al., 1997; Stackebrandt \& Schumann, 2000).

Characteristics that differentiate strain $3-6^{\mathrm{T}}$ from other representatives of the nearest neighbours detected by $16 \mathrm{~S}$ rRNA gene sequence analysis are given in Table 2. It is evident from the genotypic and phenotypic data presented that strain $3-6^{T}$ represents a novel species of a new genus within the suborder Micrococcineae, for which the name Ruania albidiflava gen. nov., sp. nov. is proposed.

\section{Description of Ruania gen. nov.}

Ruania (Ru.an'i.a. N.L. fem. n. Ruania named after Ji-Sheng Ruan, a Chinese microbiologist who has made great contributions to the development of actinomycete taxonomy in China).

Table 1. Patterns of $16 \mathrm{~S}$ rRNA gene signature nucleotides that define strain $3-6^{\top}$, the genera Beutenbergia, Georgenia and Salana and the family Bogoriellaceae

Positions are numbered according to the E. coli numbering scheme. The following signature nucleotides were identical in all taxa analysed: $41: 401(\mathrm{G}-\mathrm{C}), 45: 396$ (U-G), 142:221 (C-G), 248:276 (C-G), $258: 268$ (G-C), 293:304 (G-U), 379:384 (C-G), 407:435 (A-U), 502:543 (G-C), 586:755 (C-G), $591: 648$ (U-A), 630 (C), 660:745 (G-C), 668:738 (A-U), 670:736 (A-U), $1244: 1293$ (C-G) and $1310: 1327(\mathrm{G}-\mathrm{C})$.

\begin{tabular}{|lccccc|}
\hline Position & Strain 3-6 $^{\mathbf{T}}$ & Georgenia & Bogoriellaceae & Beutenbergia & Salana \\
\hline $66: 99$ & $\mathrm{~A}-\mathrm{U}$ & $\mathrm{A}-\mathrm{U}$ & $\mathrm{A}-\mathrm{U}$ & $\mathrm{G}-\mathrm{U}$ & $\mathrm{G}-\mathrm{U}$ \\
$140: 223$ & $\mathrm{C}-\mathrm{G}$ & $\mathrm{G}-\mathrm{U}$ & $\mathrm{G}-\mathrm{U}$ & $\mathrm{G}-\mathrm{U}$ & $\mathrm{G}-\mathrm{U}$ \\
$144: 178$ & $\mathrm{U}-\mathrm{G}$ & $\mathrm{U}-\mathrm{G}$ & $\mathrm{U}-\mathrm{G}$ & $\mathrm{C}-\mathrm{G}$ & $\mathrm{C}-\mathrm{G}$ \\
$589: 650$ & $\mathrm{U}-\mathrm{A}$ & $\mathrm{U}-\mathrm{A}$ & $\mathrm{C}-\mathrm{G}$ & $\mathrm{U}-\mathrm{A}$ & $\mathrm{U}-\mathrm{A}$ \\
$602: 636$ & $\mathrm{G}-\mathrm{U}$ & $\mathrm{C}-\mathrm{G}$ & $\mathrm{C}-\mathrm{G}$ & $\mathrm{C}-\mathrm{G}$ & $\mathrm{C}-\mathrm{G}$ \\
610 & $\mathrm{~A}$ & $\mathrm{~A}$ & $\mathrm{~A}$ & $\mathrm{~A}$ & $\mathrm{U}$ \\
$612: 628$ & $\mathrm{U}-\mathrm{A}$ & $\mathrm{G}-\mathrm{C}$ & $\mathrm{C}-\mathrm{G}$ & $\mathrm{G}-\mathrm{C}$ & $\mathrm{C}-\mathrm{G}$ \\
$616: 624$ & $\mathrm{G}-\mathrm{C}$ & $\mathrm{G}-\mathrm{C}$ & $\mathrm{G}-\mathrm{C}$ & $\mathrm{G}-\mathrm{C}$ & $\mathrm{G}-\mathrm{U}$ \\
$615: 625$ & $\mathrm{~A}-\mathrm{U}$ & $\mathrm{A}-\mathrm{U}$ & $\mathrm{G}-\mathrm{C}$ & $\mathrm{A}-\mathrm{U}$ & $\mathrm{A}-\mathrm{U}$ \\
$839: 847$ & $\mathrm{C}-\mathrm{G}$ & $\mathrm{C}-\mathrm{G}$ & $\mathrm{C}-\mathrm{G}$ & $\mathrm{U}-\mathrm{A}$ & $\mathrm{C}-\mathrm{G}$ \\
863 & $\mathrm{U}$ & $\mathrm{U}$ & $\mathrm{U}$ & $\mathrm{A}$ & $\mathrm{U}$ \\
$1133: 1141$ & $\mathrm{~A}-\mathrm{U}$ & $\mathrm{G}-\mathrm{C}$ & $\mathrm{A}-\mathrm{U}$ & $\mathrm{A}-\mathrm{U}$ & $\mathrm{A}-\mathrm{U}$ \\
$1134: 1140$ & $\mathrm{C}-\mathrm{G}$ & $\mathrm{G}-\mathrm{C}$ & $\mathrm{C}-\mathrm{G}$ & $\mathrm{C}-\mathrm{G}$ & $\mathrm{C}-\mathrm{G}$ \\
$1254: 1283$ & $\mathrm{G}-\mathrm{U}$ & $\mathrm{G}-\mathrm{C}$ & $\mathrm{G}-\mathrm{C}$ & $\mathrm{G}-\mathrm{C}$ & $\mathrm{G}-\mathrm{C}$ \\
$1263: 1272$ & $\mathrm{G}-\mathrm{U}$ & $\mathrm{G}-\mathrm{U}$ & $\mathrm{A}-\mathrm{U}$ & $\mathrm{A}-\mathrm{U}$ & $\mathrm{A}-\mathrm{U}$ \\
$1414: 1486$ & $\mathrm{U}-\mathrm{G}$ & $\mathrm{C}-\mathrm{G}$ & $\mathrm{C}-\mathrm{G}$ & $\mathrm{U}-\mathrm{A}$ & $\mathrm{U}-\mathrm{A}$ \\
& & & & & \\
\hline
\end{tabular}

*Errors in the signatures indicated in Altenburger et al. (2002) have been corrected here. 
Table 2. Differential characteristics of strain $3-6^{\top}$ and related taxa

Data for reference taxa were taken from Altenburger et al. (2002) (Georgenia), Groth et al. (1997) (Bogoriella), Groth et al. (1999b) (Beutenbergia) and von Wintzingerode et al. (2001) (Salana). All taxa have the same major menaquinone, MK- $8\left(\mathrm{H}_{4}\right)$. DNA G+C contents given are for the type strain of the type species.

\begin{tabular}{|c|c|c|c|c|c|}
\hline Characteristic & Strain $3-6^{\mathrm{T}}$ & Georgenia & Bogoriella & Beutenbergia & Salana \\
\hline Cell morphology & Coccoid & Rod-coccus & $\begin{array}{l}\text { Irregular rod, } \\
\text { coccoid }\end{array}$ & Rod-coccus & $\begin{array}{l}\text { Rod, coccoid, } \\
\text { club-like }\end{array}$ \\
\hline $\begin{array}{l}\text { DNA G + C content } \\
(\mathrm{mol} \%)\end{array}$ & 70 & 70 & 70 & 71 & 75 \\
\hline Interpeptide bridge & $\begin{array}{c}\text { L-Lys-Gly-L-Glu- } \\
\text { L-Glu (A4 } \alpha)\end{array}$ & $\begin{array}{l}\text { L-Lys-L-Glu } \\
\text { (A4 } \alpha)\end{array}$ & $\begin{array}{l}\text { L-Lys-L-Ala-L- } \\
\text { Ala-L-Glu (A4 } \alpha)\end{array}$ & $\begin{array}{l}\text { L-Lys-L-Glu } \\
\text { (A4 } 4 \text { ) }\end{array}$ & $\begin{array}{l}\text { L-Orn-L-Glu } \\
(\mathrm{A} 4 \beta)\end{array}$ \\
\hline Polar lipids* & PG, DPG, 1GL & $\begin{array}{c}\text { PG, DPG, PIM, } \\
\text { 2PL, GL }\end{array}$ & PI, PG, DPG, 1PL & PI, DPG, 3PL & PG, DPG, PLs \\
\hline Major fatty $\operatorname{acid}(\mathrm{s})$ & $\begin{array}{l}\text { anteiso- } \mathrm{C}_{15: 0} \\
\text { anteiso- } \mathrm{C}_{17: 0} \\
\quad \text { iso- } \mathrm{C}_{16: 0}\end{array}$ & $\begin{array}{c}\text { anteiso- } \mathrm{C}_{15: 0} \\
\text { iso- } \mathrm{C}_{14: 0} \\
\text { iso- } \mathrm{C}_{15: 1}\end{array}$ & anteiso- $\mathrm{C}_{15: 0}$ & $\begin{array}{l}\text { iso- } \mathrm{C}_{15: 0} \\
\text { anteiso- } \mathrm{C}_{15: 0}\end{array}$ & $\begin{array}{l}\text { iso- } \mathrm{C}_{16: 0} \\
\mathrm{C}_{14: 0}, \mathrm{C}_{16: 0}\end{array}$ \\
\hline
\end{tabular}

${ }^{\star}$ DPG, Diphosphatidylglycerol; $n \mathrm{GL}, n$ unknown glycolipid(s); PG, phosphatidylglycerol; PI, phosphatidylinositol; PIM, phosphatidylinositol mannoside; $n$ PL, $n$ unknown phospholipid(s).

Gram-positive, aerobic, mesophilic, moderately halotolerant, non-acid-fast, non-motile, non-spore-forming cocci. The rod-coccus life cycle is not detected. The peptidoglycan type is A $4 \alpha$ with an L-Lys-Gly-L-Glu-L-Glu interpeptide bridge. The predominant menaquinone is $\mathrm{MK}-8\left(\mathrm{H}_{4}\right)$. The main fatty acid is anteiso- $\mathrm{C}_{15: 0}$ (12-methyl tetradecanoic acid). The major polar lipids are phosphatidylglycerol, diphosphatidylglycerol and one unknown glycolipid. Mycolic acids are absent. The $16 \mathrm{~S}$ rRNA gene sequence signature nucleotides are listed in Table 1 . The genus belongs phylogenetically to the suborder Micrococcineae, order Actinomycetales. The type species is Ruania albidiflava.

\section{Description of Ruania albidiflava sp. nov.}

Ruania albidiflava (al.bi.di.fla'va. L. adj. albidus white; L. fem. adj. flava yellow; N.L. fem. adj. albidiflava whitish yellow).

Cells are $0.5-0.8 \mu \mathrm{m}$ in diameter. Colonies are convex and moist, with a pale yellow colour. Growth occurs at 20$37^{\circ} \mathrm{C}$ with an optimum at $28^{\circ} \mathrm{C}$, and at a wide initial $\mathrm{pH}$ range of 5.5-12.5 with an optimum at $\mathrm{pH}$ 6.5-10.5. Can tolerate up to $10 \%(\mathrm{w} / \mathrm{v}) \mathrm{NaCl}$. Catalase-positive, oxidase-negative. The methyl red test is positive, but indole and Voges-Proskauer reactions are negative. Nitrate is reduced to nitrite. $\mathrm{H}_{2} \mathrm{~S}$ is not produced. Potato starch is decomposed, but adenine, casein, aesculin, gelatin, hippurate, hypoxanthine, tyrosine, urea and xanthine are not. Acids are produced from arbutin, salicin, D-ribose, methyl $\beta$-D-xylopyranoside, D-fructose, aesculin, D-maltose, D-arabinose, L-arabinose, D-xylose, L-rhamnose, D-lyxose and L-fucose, but not from glycerol, erythritol, L-xylose, D-adonitol, D-galactose, D-glucose, D-mannose, L-sorbose, dulcitol, inositol, D-mannitol, D-sorbitol, methyl $\alpha$-D-mannopyranoside, methyl $\alpha$-D-glucopyranoside, $N$-acetylglucosamine, amygdalin, D-cellobiose, D-lactose, D-melibiose, sucrose, D-trehalose, inulin, D-melezitose, D-raffinose, starch, glycogen, xylitol, gentiobiose, D-turanose, D-tagatose, D-fucose, DL-arabitol, potassium 2-ketogluconate or potassium 5-ketogluconate. Utilizes the following substrates as sole carbon sources: acetate, D-lactose, D-melezitose, L-alanine, L-cysteine, L-leucine, L-methionine, L-proline, methyl $\alpha$-Dglucoside, oxalate, D-fructose, D-glucose, D-glutamic acid, D-maltose, D-ribose, D-sorbitol, D-trehalose, glycerol, L-arginine, L-fucose and sucrose. The following substrates are not utilized: citrate, D-cellobiose, D-galactose, D-inulin, D-lactulose, D-mannitol, D-mannose, D-raffinose, D-rhamnose, D-sorbose, D-xylose, dulcitol, erythritol, glycogen, inositol, L-arabinose, L-leucinamide, L-ornithine, L-phenylalanine, L-tyrosine, L-valine, malate, malonate, nicotinamide, salicin and succinate. In the API ZYM assay, tests are positive for cystine arylamidase, $\alpha$-fucosidase, alkaline phosphatase, esterase lipase (C8), leucine arylamidase, valine arylamidase, acid phosphatase, naphthol-AS-BI-phosphohydrolase, $\alpha$-galactosidase, $\beta$-galactosidase, $\alpha$-glucosidase, $\beta$-glucosidase, $N$-acetyl- $\beta$-glucosaminidase and $\alpha$-mannosidase, but negative for esterase (C4), lipase (C14), trypsin, chymotrypsin and $\beta$-glucuronidase. Cells are susceptible to ampicillin $(10 \mu \mathrm{g})$, chloramphenicol $(30 \mu \mathrm{g})$, ciprofloxacin (5 $\mu \mathrm{g})$, erythromycin $(15 \mu \mathrm{g})$, gentamicin $(10 \mu \mathrm{g})$, kanamycin $(30 \mu \mathrm{g})$, neomycin $(30 \mu \mathrm{g})$, polymyxin B (300 IU), rifampicin $(15 \mu \mathrm{g})$ and streptomycin $(10 \mu \mathrm{g})$. Not susceptible to nitrofurantoin $(300 \mu \mathrm{g})$ or oxacillin $(1 \mu \mathrm{g})$. Wholecell sugars are galactose and glucose. The $\mathrm{G}+\mathrm{C}$ content of the genomic DNA is $69.8 \mathrm{~mol} \%$. Other chemotaxonomic characteristics are as described for the genus.

The type strain, $3-6^{\mathrm{T}}\left(=\mathrm{CGMCC} 4.3142^{\mathrm{T}}=\mathrm{DSM} 18029^{\mathrm{T}}=\right.$ JCM $13910^{\mathrm{T}}=$ PCM $2644^{\mathrm{T}}$ ), was isolated from farmland soil collected in Shandong Province, China. 


\section{Acknowledgements}

This work was supported by the Chinese Academy of Sciences-Polish Academy of Sciences Exchange Scheme and by the Knowledge Innovation Project of the Chinese Academy of Sciences. We are grateful to Professor Ji-Sheng Ruan for helpful suggestions.

\section{References}

Altenburger, P., Kämpfer, P., Schumann, P., Vybiral, D., Lubitz, W. \& Busse, H.-J. (2002). Georgenia muralis gen. nov., sp. nov., a novel actinobacterium isolated from a medieval wall painting. Int $J$ Syst Evol Microbiol 52, 875-881.

Chun, J. \& Goodfellow, M. (1995). A phylogenic analysis of genus Nocardia with $16 \mathrm{~S}$ rRNA gene sequences. Int J Syst Bacteriol 45, 240-245.

Collins, M. D. (1985). Isoprenoid quinone analysis in classification and identification. In Chemical Methods in Bacterial Systematics, pp. 267-287. Edited by M. Goodfellow \& D. E. Minnikin. London: Academic Press.

Cui, Q., Wang, L., Huang, Y., Liu, Z. \& Goodfellow, M. (2005). Nocardia jiangxiensis sp. nov. and Nocardia miyunensis sp. nov., isolated from acidic soils. Int J Syst Evol Microbiol 55, 1921-1925.

Fitch, W. M. (1971). Toward defining the course of evolution: minimum change for a specific tree topology. Syst Zool 20, 406-416.

Gordon, R. E. \& Mihm, J. M. (1957). A comparative study of some strains received as nocardiae. J Bacteriol 73, 15-27.

Groth, I., Schumann, P., Rainey, F. A., Martin, K., Schuetze, B. \& Augsten, K. (1997). Bogoriella caseilytica gen. nov., sp. nov., a new alkaliphilic actinomycete from a soda lake in Africa. Int $J$ Syst Bacteriol 47, 788-794.

Groth, I., Schumann, P., Martin, K., Schuetze, B., Augsten, K., Kramer, I. \& Stackebrandt, E. (1999a). Ornithinicoccus hortensis gen. nov., sp. nov., a soil actinomycete which contains L-ornithine. Int J Syst Bacteriol 49, 1717-1724.

Groth, I., Schumann, P., Schuetze, B., Augsten, K., Kramer, I. \& Stackebrandt, E. (1999b). Beutenbergia cavernae gen. nov., sp. nov., an L-lysine-containing actinomycete isolated from a cave. Int J Syst Bacteriol 49, 1733-1740.

Groth, I., Schumann, P., Weiss, N., Schuetze, B., Augsten, K. \& Stackebrandt, E. (2001). Ornithinimicrobium humiphilum gen. nov., sp. nov., a novel soil actinomycete with L-ornithine in the peptidoglycan. Int J Syst Evol Microbiol 51, 81-87.

Groth, I., Schumann, P., Schutze, B., Augsten, K. \& Stackebrandt, E. (2002). Knoellia sinensis gen. nov., sp. nov. and Knoellia subterranea sp. nov., two novel actinobacteria isolated from a cave. Int J Syst Evol Microbiol 52, 77-84.

Gu, Q., Luo, H., Zheng, W., Liu, Z. \& Huang, Y. (2006). Pseudonocardia oroxyli sp. nov., a novel actinomycete isolated from surface-sterilized Oroxylum indicum root. Int J Syst Evol Microbiol 56, 2193-2197.

Hammond, P. M. (1995). Described and estimated species numbers: an objective assessment of current knowledge. In Microbial Diversity and Ecosystem Function, pp. 29-71. Edited by D. Allsopp, R. R. Colwell \& D. L. Hawksworth. Wallingford, UK: CAB International.

Huang, Y., Li, W., Wang, L., Lanoot, B., Vancanneyt, M., Rodriguez, C., Liu, Z., Swings, J. \& Goodfellow, M. (2004). Streptomyces glauciniger sp. nov., a novel mesophilic streptomycete isolated from soil in south China. Int J Syst Evol Microbiol 54, 2085-2089.

Kämpfer, M. \& Kroppenstedt, R. M. (1996). Numerical analysis of fatty acid patterns of coryneform bacteria and related taxa. Can J Microbiol 42, 989-1005.

Kimura, M. (1980). A simple method for estimating evolutionary rates of base substitutions through comparative studies of nucleotide sequences. J Mol Evol 16, 111-120.
Kumar, S., Tamura, K. \& Nei, M. (2004). MEGA3: integrated software for molecular evolutionary genetics analysis and sequence alignment. Brief Bioinform 5, 150-163.

Lechevalier, M. P. \& Lechevalier, H. A. (1970). Chemical composition as a criterion in the classification of aerobic actinomycetes. Int $J$ Syst Bacteriol 20, 435-443.

Lechevalier, H. A. \& Lechevalier, M. P. (1980). The chemotaxonomy of actinomycetes. In Actinomycete Taxonomy, pp. 277-284. Edited by A. Dietz \& D. W. Thayer. Arlington, VA: Society of Industrial Microbiology.

Lechevalier, M. P., De Bièvre, C. \& Lechevalier, H. A. (1977). Chemotaxonomy of aerobic actinomycetes: phospholipid composition. Biochem Syst Ecol 5, 249-260.

MacKenzie, S. L. \& Tenaschuk, D. (1974). Gas-liquid chromatography of N-heptafluorobutyryl isobutyl esters of amino acids. J Chromatogr 97, 19-24.

Marmur, J. \& Doty, P. (1962). Determination of the base composition of deoxyribonucleic acid from its thermal denaturation temperature. J Mol Biol 5, 109-118.

Martin, K., Schumann, P., Rainey, F. A., Schuetze, B. \& Groth, I. (1997). Janibacter limosus gen. nov., sp. nov., a new actinomycete with meso-diaminopimelic acid in the cell wall. Int J Syst Bacteriol 47, 529-534.

Minnikin, D. E., Alshamaony, L. \& Goodfellow, M. (1975). Differentiation of Mycobacterium, Nocardia, and related taxa by thin-layer chromatographic analysis of whole-organism methanolysates. J Gen Microbiol 88, 200-204.

Minnikin, D. E., O'Donnell, A. G., Goodfellow, M., Alderson, G., Athalye, M., Schaal, A. \& Parlett, J. H. (1984). An integrated procedure for the extraction of isoprenoid quinones and polar lipids. J Microbiol Methods 2, 233-241.

Saitou, N. \& Nei, M. (1987). The neighbor-joining method: a new method for reconstructing phylogenetic trees. Mol Biol Evol 4, 406-425.

Sasser, M. (1990). Identification of bacteria by gas chromatography of cellular fatty acids. MIDI Technical Note 101. Newark, DE: MIDI Inc.

Schleifer, K. H. (1985). Analysis of the chemical composition and primary structure of murein. Methods Microbiol 18, 123-156.

Schleifer, K. H. \& Kandler, O. (1972). The peptidoglycan types of the bacterial cell walls and their taxonomic implications. Bacteriol Rev 36, 407-477.

Schleifer, K. H. \& Seidl, P. H. (1985). Chemical composition and structure of murein. In Chemical Methods in Bacterial Systematics, pp. 201-219. Edited by M. Goodfellow \& D. E. Minnikin. London: Academic Press.

Stackebrandt, E. \& Schumann, P. (2000). Description of Bogoriellaceae fam. nov., Dermacoccaceae fam. nov., Rarobacteraceae fam. nov. and Sanguibacteraceae fam. nov. and emendation of some families of the suborder Micrococcineae. Int J Syst Evol Microbiol 50, 1279-1285.

Stackebrandt, E., Rainey, F. A. \& Ward-Rainey, N. L. (1997). Proposal for a new hierarchic classification system, Actinobacteria classis nov. Int J Syst Bacteriol 47, 479-491.

Takahashi, Y., Matsumoto, A., Morisaki, K. \& Omura, S. (2006). Patulibacter minatonensis gen. nov., sp. nov., a novel actinobacterium isolated using an agar medium supplemented with superoxide dismutase, and proposal of Patulibacteraceae fam. nov. Int J Syst Evol Microbiol 56, 401-406.

von Wintzingerode, F., Göbel, U. B., Siddiqui, R. A., Rösick, U., Schumann, P., Frühling, A., Rohde, M., Pukall, R. \& Stackebrandt, E. (2001). Salana multivorans gen. nov., sp. nov., a novel actinobacterium isolated from an anaerobic bioreactor and capable of selenate reduction. Int J Syst Evol Microbiol 51, 1653-1661. 
Wu, C., Lu, X., Qin, M., Wang, Y. \& Ruan, J. (1989). Analysis of menaquinone compound in microbial cells by HPLC. Microbiology [English translation of Microbiology (Beijing)] 16, 176-178.
Yassin, A. F., Rainey, F. A., Brzezinka, H., Burghardt, J., Lee, H. J. \& Schaal, K. P. (1995). Tsukamurella inchonensis sp. nov. Int J Syst Bacteriol 45, 522-527. 